
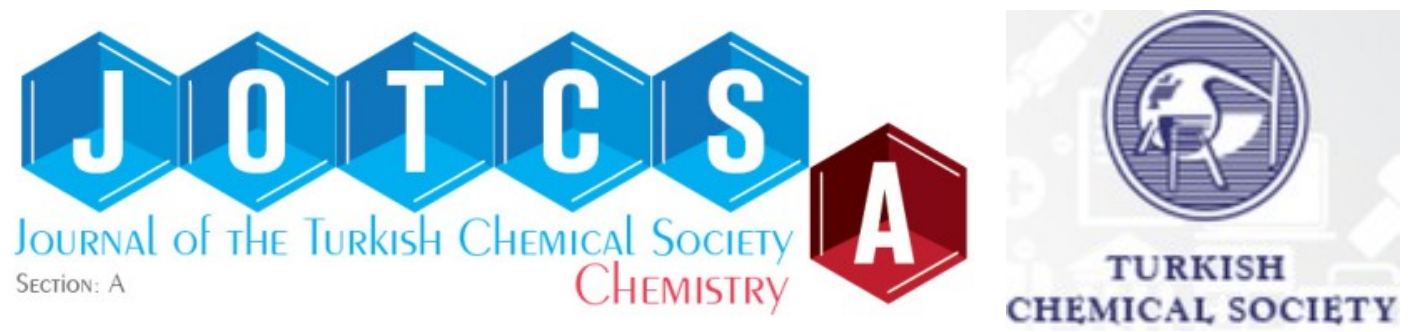

\title{
The Phytochemical, Proximate and Mineral Contents of Cassava Leaves and Nutritive Values of Associated Arthropod Pests
}

\author{
Sebiomo Adewole* $\square$, Banjo F. Mary $\triangle$ D \\ Department of Biological Sciences, Tai Solarin University of Education Ijagun, Ijebu-Ode, Nigeria
}

Abstract: Cassava (Manihot esculenta) is the most important staple food crops grown in Nigeria. This study investigated the following; (1) the nutritive values of insect pests associated with cassava leaves (2) phytochemical, mineral, and proximate content of cassava leaves (3) the antimicrobial activities of cassava leaves. Phytochemicals (Alkaloids, flavonoids, saponins, tannin, phytate, oxalate, phenol, and cyanogenic glycosides), proximate (ash, moisture, crude fiber, crude protein, crude fats), mineral $(\mathrm{Zn}, \mathrm{Fe}, \mathrm{Cu}, \mathrm{Mg}, \mathrm{Ca}, \mathrm{K}, \mathrm{Fe}, \mathrm{Mn}, \mathrm{Na})$ and vitamin contents of samples were analyzed using the method of Association of Official Analytical Chemists. Results showed high amounts of crude protein, crude fat, moisture content, carbohydrate, and mineral content in all arthropod insects examined. The highest quantity of $\mathrm{Ca}(1152.84 \pm 0.67 \mathrm{mg} / 100 \mathrm{~g})$ was obtained in ABF4, followed by ABF5 $(1148.72 \pm 1.09 \mathrm{mg} / \mathrm{kg})$. The lowest phenol content of $0.10 \pm 0.00 \mathrm{ppm}$ was obtained in the cassava branch. The leaf recorded the highest phenol value of $0.74 \pm 0.01 \mathrm{ppm}$. The highest alkaloid value was $3.51 \pm 2.45 \mathrm{ppm}$ in Manihot esculenta branch. The highest crude protein and crude fat values of $3.41 \pm 0.13 \%$ and $4.83 \pm 0.02 \%$ were obtained in ABF5. Vitamin C was found in very high quantities compared to the other types of vitamins examined in this work. The highest Vitamin C content of $34.930 \pm 0.136 \mathrm{mg} / 100 \mathrm{~g}$ was obtained. Cassava leaves and the arthropod pests are good sources of nutrients. Cassava leaves could also be used as an antimicrobial agent.

Keywords: Cassava, phenol, minerals, crude protein, crude fat.

Submitted: May 07, 2020. Accepted: July 09, 2020.

Cite this: Sebiomo A, Banjo FM. The Phytochemical, Proximate and Mineral Contents of Cassava Leaves and Nutritive Values of Associated Arthropod Pests. JOTCSA. 2020;7(3):661-74.

DOI: https://doi.org/10.18596/jotcsa.733516.

*Corresponding author. E-mail: rev20032002@yahoo.com.

\section{INTRODUCTION}

Cassava (Manihot esculenta) is an essential food crop grown and commonly consumed in the tropics (1). Cassava plays a significant role in making sure food security in a developing country; namely, Nigeria, is sustained. Approximately 750 million people, of which $45 \%$ of sub-Saharan Africans, depend entirely on cassava as a primary food source (1). All the parts of the crop in its entirety are useful for consumption by man and animals. Cassava is easily cultivated, and it adapts to soils with depleted fertility, low rainfall, high temperature, and resistance to drought (2). These essential qualities are vital in adapting to climate change. Cassava constitutes an important source of income for a lot of farmers, traders, and industries. It also contributes in no small measure to the economy of most developing and tropical countries like Nigeria through processing it into various products. The roots 
are processed into flour, starch, and other end products like chips, flakes, biofuel, textiles, and glue (3).

Arthropods are found in the Phylum euartbropoda which includes insects, arachnids, myriapods, and crustaceans. Arthropods possess jointed limbs and cuticles containing chitin as well as calcium carbonate, while the body plan is made up of segments, and each of these is made up of a pair of appendages. The rigid cuticle slows down growth; hence, they are replaced periodically by molting. Arthropods aerate and mix the soil, which aids plants and microbial growth. They also control the population size of other soil organisms and help in breaking down organic materials. Arthropods recognizably affect plant performance, competition among plants thereby impacting the plant community composition due to series of mechanisms which include below ground herbivory as well as accelerates cycling of nutrient as a result of the action of arthropod detritivores (4).

The total count of arthropods attached to plants, which includes and not limited to cassava, is one of the crucial determinants of the diversity of species on land thus constituting the most critical ecological variable in relationships among living organisms which includes processes that are important for maintaining biodiversity in tropical forests $(5 ; 6)$. Species attached to plant species differ considerably. These variations are influenced by several factors such which include geography, abundance, and geological history, biochemical composition, phytochemical, mineral composition, diversity of habitat, as well as the structure of the host plant. Factors such as temperature and patterns of rainfall, interactions among living organisms can affect them in their reproduction rate, adaptation, and longevity (7).

Arthropods possess many features, including high diversity and small body size, that make them essential for environmental monitoring. Arthropods are the most species-rich and morphologically diverse animal group of living organisms on earth (8). Arthropods sampling can be carried out using various survey methods. Thus, arthropods are often used as biological indicators of ecosystem integrity and could be used reliably to infer ecosystem function and habitat conditions (9).

Cassava (Manihot esculenta) leaves are a good source of dietary proteins and vitamin-K, which has a potential role in bone-strengthening by stimulating cell activity in the bones. Cassava carries some of the valuable B-complex group of vitamins such as folates, thiamin, pyridoxine (vitamin B-6), riboflavin, and pantothenic acid. It is one of the chief sources of some essential minerals like zinc, magnesium, copper, iron, and manganese. Also, it has adequate amounts of potassium, which is an essential component of cell and body fluids that help regulate heart rate and blood pressure. Hence this study investigated the following; (1) the nutritive values of insect pests associated with cassava leaves (2) phytochemical, mineral and proximate content of cassava leaves (3) the antimicrobial activities of cassava leaves.

\section{MATERIALS AND METHODS}

\section{Study Area}

The experiment was carried out in five cassava farmlands in Abapawa, Odogbolu Local Government Area of Ogun State (Fig. 1). The collection was done between the periods; April to August 2019. The region lies between

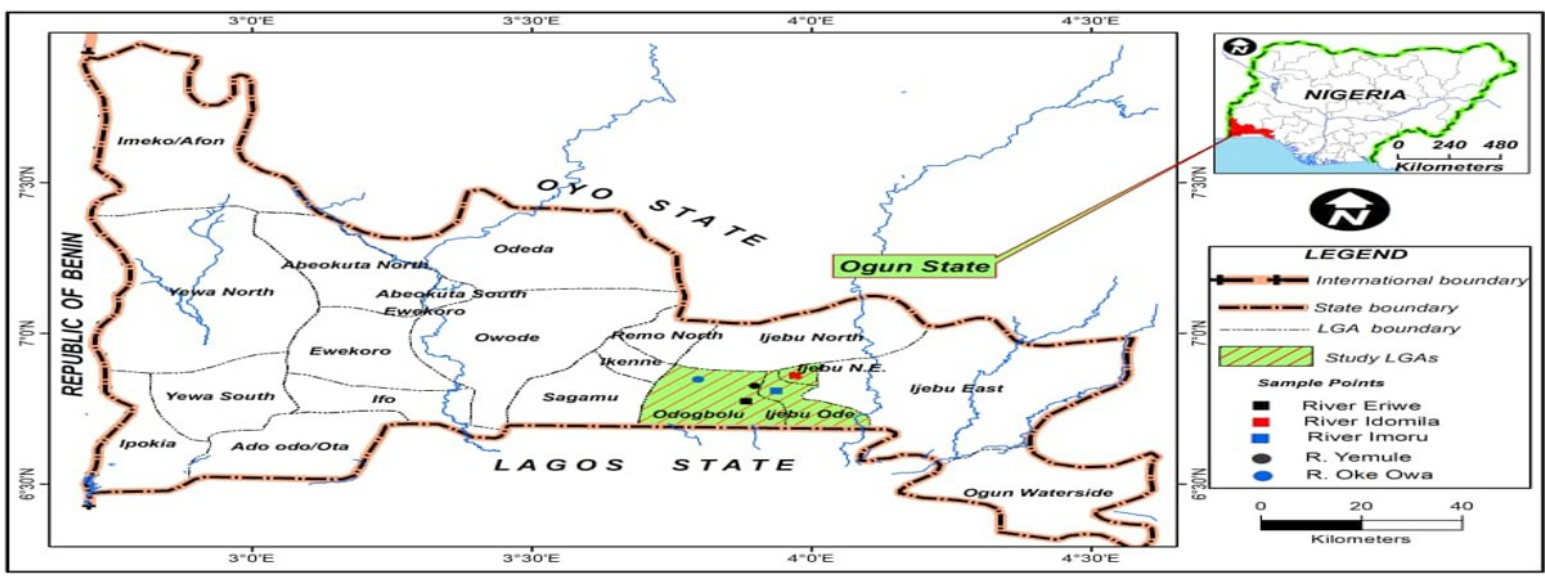

Figure 1. Map showing the location of sampling sites. 
6०46'37' N latitude and 355'30' E longitude. The five cassava farmlands have a plot size of $18 \mathrm{~m} \times 36 \mathrm{~m}$ (648 sqm) each.

Plant Material, Sample Preparation, and Extraction

Manihot esculenta leaves were collected from farmlands in Abapawa, Odogbolu Local Government area Ogun State, Nigeria. The leaves were sorted, de-stalked, and washed thoroughly in water several times until they became clean and free of debris, after which they were sun-dried. Dried leaf materials were pulverized into fine powdered form, filtered through a mesh, and an approximate amount of powdered material was subjected to Soxhlet extraction method with analytical grade solvents (ethanol and acetone). The crude leaf extracts obtained were evaporated completely and processed for further use.

\section{Visual Sampling Method and Collection of Arthropods}

A selected sample of cassava plants was used. Ten stands of cassava plants, which were observed for arthropod pests in each location of the leaves, stems, branch and the root, were tagged in each farmland. Arthropod pests affecting cassava plants were surveyed on the leaves, stems, and roots of the selected cassava stand. Arthropod pests were collected separately on different specimen bottles and labeled accordingly based on the part of the plant collection and the date of collection. The counts were made before 08:00h (GMT) each day to avoid excursive mobility of the adult pest after this time, but the migration of the fastmoving and mobile adults from one plot to the other could not be avoided.

\section{Preservation of Arthropod Pests}

Arthropods pests collected were sorted according to the species. These were later preserved separately in different specimen bottles containing $70 \%$ ethanol.

\section{Identification of Arthropods}

The cassava arthropods collected were then taken to the Department of Agriculture and Environmental Biology, University of Ibadan, Nigeria, for identification.

\section{Phytochemical and Proximate Analysis of Samples}

Phytochemicals (Alkaloids, flavonoids, saponins, tannin, phytate, oxalate, phenol, cyanogenic glycosides), proximate content (ash, moisture, crude fiber, crude protein, crude fats), mineral contents $(\mathrm{Zn}, \mathrm{Fe}, \mathrm{Cu}, \mathrm{Mg}, \mathrm{Ca}, \mathrm{K}, \mathrm{Fe}, \mathrm{Mn}, \mathrm{Na})$ were analyzed using the method of AOAC (10).

\section{Determination of Alkaloid Content}

$0.5 \mathrm{~g}$ of the sample was dissolved in $96 \%$ ethanol: $20 \% \mathrm{H}_{2} \mathrm{SO}_{4}(1: 1)$. $1 \mathrm{~mL}$ of the filtrate was added to $5 \mathrm{~mL}$ of $60 \%$ sulfuric acid and left undisturbed for 5 minutes. Then, $5 \mathrm{~mL}$ of $0.5 \%$ formaldehyde was added and left to stand for 3 hours. The absorbance was read at $565 \mathrm{~nm}$.

\section{Determination of Flavonoid Content}

The flavonoid content was determined using the aluminum chloride colorimetric assay method. An aliquot of $500 \mu \mathrm{L}$ extract was mixed with the following: $1500 \mu \mathrm{L}$ of $99.9 \%$ ethanol, $100 \mu \mathrm{L}$ of $1 \mathrm{M}$ potassium acetate, $100 \mu \mathrm{L}$ of $10 \%$ aluminum chloride and $3000 \mu \mathrm{L}$ of distilled water. The resulting mixture was incubated for 30 minutes at room temperature and corresponding absorbance measured at 415 $\mathrm{nm}$.

\section{Determination of Phenolic Content}

$50 \mu \mathrm{L}$ of each of the samples was mixed with 3 $\mathrm{mL}$ of distilled water and $250 \mu \mathrm{L}$ of a 1 in 10 diluted Folin-Ciocalteu phenol reagent. The mixtures were allowed to stand for 5 minutes, after which $750 \mu \mathrm{L}$ of $20 \% \mathrm{Na}_{2} \mathrm{CO}_{3}$ was added to each. They were thoroughly mixed and incubated for 30 minutes at room temperature in a dark place. Absorbance was measured at $760 \mathrm{~nm}$ using a UV-Vis Spectrophotometer.

\section{Determination of Saponin Content}

The samples were ground, and $20 \mathrm{~g}$ of each plant samples were dispersed in $200 \mathrm{~mL}$ of $20 \%$ ethanol. The suspension was heated over a hot water bath for $4 \mathrm{~h}$ with continuous stirring at about $55^{\circ} \mathrm{C}$. The mixture was filtered, and the residue re-extracted with another $200 \mathrm{ml}$ of $20 \%$ ethanol. The extracts were reduced to 40 $\mathrm{mL}$ over a water bath at about $90^{\circ} \mathrm{C}$. The extract was then transferred into a $250 \mathrm{~mL}$ separator funnel, and $20 \mathrm{~mL}$ of diethyl ether was added and shaken vigorously. The aqueous layer was recovered while the ether layer was discarded. The process was repeated, after which $60 \mathrm{~mL}$ of $\mathrm{n}$-butanol was added. The combined $n$-butanol extracts were washed twice with $10 \mathrm{~mL}$ of $5 \%$ aqueous sodium chloride. The remaining solution was heated in a water bath. After evaporation, the samples were dried in the oven to a constant weight. The saponin content was then calculated.

\section{Determination of Tannins}

$0.2 \mathrm{~g}$ of the sample was measured into a $50 \mathrm{~mL}$ beaker. $20 \mathrm{~mL}$ of $50 \%$ methanol was added 
and covered with parafilm and placed in a water bath at $77-80^{\circ} \mathrm{C}$ for 1 hour. It was then shaken thoroughly. The extract was filtered using a double-layered Whatman No. 1 filter paper. The filtrate was then dispensed into a $100 \mathrm{~mL}$ volumetric flask. $20 \mathrm{~mL}$ of water, $2.5 \mathrm{ml}$ FolinDenis reagent and $10 \mathrm{~mL}$ of $17 \% \mathrm{Na}_{2} \mathrm{CO}_{3}$ were added and mixed thoroughly. The mixture was made up to the marked level with distilled water mixed well and left undisturbed for 20 minutes for the development of a bluish-green color. The absorbance was read after color development on a UV-Vis spectrophotometer model 752, at a wavelength of $760 \mathrm{~nm}$.

\section{Determination of Phytate Content}

$5 \mathrm{~g}$ of the sample was extracted with $20 \mathrm{~mL}$ of $3 \%$ trichloroacetic acid and filtered. $5 \mathrm{~mL}$ of $1 \mathrm{M}$ $\mathrm{NaOH}$ was added to precipitate the phytate as ferric phytate and converted to ferric hydroxide and soluble sodium phytate. The precipitate was dissolved with hot $3.2 \mathrm{M} \mathrm{HNO}_{3}$, and the absorbances were read immediately at $480 \mathrm{~nm}$.

\section{Determination of the Oxalate Content}

$150 \mathrm{~mL}$ of $15 \mathrm{~N} \mathrm{H}_{2} \mathrm{SO}_{4}$ was added to $5 \mathrm{~g}$ of the pulverized sample, and the solution was carefully stirred intermittently with a magnetic stirrer for 30 minutes and filtered using Whatman No 1 filter paper, after which $25 \mathrm{~mL}$ of the filtrate was collected and titrated against $0.05 \mathrm{M}$ standardized $\mathrm{KMnO} 4$ solution until a faint pink color appeared that persisted for 30 seconds.

\section{Determination of Cyanogenic Glycoside}

$5 \mathrm{~g}$ of powdered sample was dissolved in $50 \mathrm{~mL}$ of distilled water in a conical flask, and the extraction was allowed to stand over-night, then filtered. $1 \mathrm{~mL}$ of sample filtered was mixed with $4 \mathrm{~mL}$ alkaline picrate in a corked test tube and incubated in a water bath for 5 mins. After color development (reddish-brown color) the absorbance was read at 490nm.

\section{Moisture Content Analysis}

The moisture content was determined by heating $10.0 \mathrm{~g}$ of each sample to constant weight in a hot air-circulating thermostatic oven at $110^{\circ} \mathrm{C}$, cooling in desiccators, and obtaining a constant weight using Mettler P1210 Analytical Balance, Switzerland.

$\% \mathrm{MC}=10^{2}[$ (wt. of crucible + sample before drying $)$ - (dry wt. of crucible + sample)]/wt. of sample

\section{Ash Content Analysis}

Percentage ash was determined by charring 3.0 $\mathrm{g}$ of the sample on a hot plate in a fume cupboard and incinerating in a pre-heated muffle furnace (Bamford, Sheffield England) at $6000 \mathrm{C}$ for $4 \mathrm{~h}$.

$\%$ Ash $=10^{2}[($ wt. of crucible + Ash $)-$ (wt. of crucible)]/wt. of the sample before dry ashing

\section{Fat Content Analysis}

The fat content was determined by exhaustively extracting $2.0 \mathrm{~g}$ of each sample for $6 \mathrm{~h}$ in a Soxhlet extractor using petroleum ether.

$\%$ Fat $=10^{2} \mathrm{Wt}$. of fat/Wt. of sample

\section{Crude protein analysis}

Crude protein was estimated by the Kjeldahl method. Total nitrogen, $\mathrm{N}$, in the sample was first determined, and $\% \mathrm{~N}$ in the food protein was multiplied with a factor, 6.25 to obtain the $\%$ total protein in the sample. The sample was digested with conc. $\mathrm{H}_{2} \mathrm{SO}_{4}$ and the digest was distilled with Markham distiller in a fume cupboard to liberate $\mathrm{NH}_{3}$ trapped into a $5 \mathrm{~mL}$ of $2 \% \mathrm{H}_{3} \mathrm{BO}_{3}$. The resulting ammonium borate was titrated against $0.01 \mathrm{M} \mathrm{H}_{2} \mathrm{SO}_{4}$.

$\% \mathrm{~N}=10^{2}[(\mathrm{Va}-\mathrm{Vb}) \times 0.01 \times 0.01401] / \mathrm{wt}$. of sample

Where $\mathrm{Va}=$ titer vol. of acid, $\mathrm{Vb}=$ titer vol. of blank

\section{Mineral analysis}

To $2.0 \mathrm{~g}$ of sample, $30 \mathrm{ml}$ of $1 \mathrm{~N} \mathrm{NH}{ }_{4} \mathrm{OAc}$ (ammonium acetate solution) was added, and the flasks were shaken on a mechanical shaker for $2 \mathrm{~h}$. The mixture was centrifuged at 2000 rpm for $10 \mathrm{~min}$, and the clear supernatant was decanted into $100 \mathrm{ml}$ volumetric flasks. About $30 \mathrm{ml}$ of ammonium acetate solution $\left(\mathrm{NH}_{4} \mathrm{OAc}\right)$ was added twice into the flasks, and shaken on a mechanical shaker for $30 \mathrm{~min}$ each, and centrifuged at $2000 \mathrm{rpm}$ and the clear supernatant was then transferred into the same volumetric flasks respectively. The sample extract was made up to $100 \mathrm{~mL}$ volume with the $\mathrm{NH}_{4} \mathrm{OAc}$ solution.

$\mathrm{Ca}, \mathrm{K}, \mathrm{Na}, \mathrm{Mn}, \mathrm{Mg}, \mathrm{Fe}, \mathrm{Zn}$, and $\mathrm{Cu}$ in samples in the samples were determined using the atomic absorption spectrophotometer fitted with a hollow cathode lamp and a fuel-rich flame (air acetylene). Sample solutions (extract) and standard solutions for each mineral were injected into the atomic absorption spectrophotometer into sample fray, and the 
mean signal response was recorded for each of the elements at their respective wavelength. The concentration of the minerals was calculated (10).

\section{Determination of Vitamins Content}

The vitamin contents (vitamins A, B1, B2, B6, $C, D, E$, and $K$ ) of the cassava leaves were determined by the methods of AOAC (10).

\section{Test microorganisms for Antimicrobial Activities}

Cultures of test microorganisms (Salmonella typhi, Escherichia coli, Pseudomonas aeruginosa, Staphylococcus aureus, Aspergillus flavus, and Fusarium oxysporum) were collected from University College Hospital Ibadan (UCH). The clinical isolates of bacteria were checked for purity and maintained on the nutrient agar plate at $4^{\circ} \mathrm{C}$ in the refrigerator until required for use.

\section{Preparation of Nutrient Agar (NA)}

$28 \mathrm{~g}$ of powdered nutrient agar was weighed on the analytical Mettler balance and dispensed into a 1-liter conical flask containing $1000 \mathrm{~mL}$ of distilled water. The suspension was then dissolved by heating in a water bath at $100^{\circ} \mathrm{C}$. Then $20 \mathrm{~mL}$ volume each of the molten agar was dispensed into McCartney bottles and sterilized inside the autoclave at $121{ }^{\circ} \mathrm{C}$ for 15 min. the sterile molten nutrient agar was allowed to cool to $40^{\circ} \mathrm{C}$ before use.

Preparation of Potato Dextrose Agar (PDA) $39 \mathrm{~g}$ of powdered PDA was weighed into a 1liter capacity conical flask containing $1000 \mathrm{~mL}$ of distilled water. The suspension was then dissolved by heating in a water bath at $100{ }^{\circ} \mathrm{C}$. $20 \mathrm{~mL}$ volume each of the molten agars were dispensed into McCartney bottles and sterilized inside the autoclave at $121{ }^{\circ} \mathrm{C}$ for $15 \mathrm{~min}$. The sterile molten nutrient agar was allowed to cool to $40^{\circ} \mathrm{C}$ before use.

\section{Test for Anti-bacterial Activity}

$15 \mathrm{~mL}$ of sterile nutrient agar was dispensed into each sterile petri dish of equal size and allowed to solidify. The surface of this sterile nutrient agar plate was streaked with a pure culture of standardized, Escherichia coli, Pseudomonas aeruginosa, and Staphylococcus aureus suspensions. A cork borer $(8 \mathrm{~mm}$ in diameter) was sterilized by flaming and used to create ditch at the center of the plate. It was then filled with plant extracts. The plates were allowed to stand for one hour for pre-diffusion of the extracts, and incubation was done at 37 ${ }^{\circ} \mathrm{C}$ for $24 \mathrm{hrs}$. At the end of the incubation period, the diameter of the zone of inhibition was measured in millimeters.

\section{Test for Antifungal Activity}

Potato Dextrose agar was melted and cooled to about $45^{\circ} \mathrm{C}$ and was then poured into clean, sterile Petri-dishes and allowed to set. The overnight cultures of $A$. flavus and $F$. oxysporum were then inoculated into the sterile Petri-dishes. The plates were gently swirled round to enable the fungal suspensions to cover the whole surface of the plates. A standard cork borer was used to cut uniform equidistant wells on the surface of the agar into which known dilutions of the extracts were added. The plates were allowed to stand for one hour for prediffusion of the extracts and incubation was done at $25{ }^{\circ} \mathrm{C}$ for $48-72 \mathrm{~h}$. The diameters of the zone of inhibition were measured and recorded.

\section{Statistical Analysis}

Data generated from this study were subjected to analysis of variance (ANOVA). Means were compared at $5 \%$ level of significance using Duncan's multiple range tests.

ANOVA was calculated as follows:

(1) The correction for mean (CM) was computed as shown below:

$$
s^{2}=\frac{1}{n-1} \sum\left(y_{i}-\bar{y}\right)^{2}
$$

(2) The total sum of squares (SS) were then determined as shown below;

$$
S S_{\text {Total }}=S S_{\text {Error }}+S S_{\text {Treatments }}
$$

(3) The treatment sum of squares (SST) was then computed

$S S T=\sum_{i=1}^{3} \frac{T_{i}^{2}}{n_{i}}-C M=$

(4) The error sum of squares (SSE) was computed;

$S S E=S S(T O T A L)-S S T$

(5) The MST, MSE, and their ratio, $F$ were computed;

$$
M S T=\frac{S S T}{k-1,} \quad M S E=\frac{S S E}{N-k,} \quad F=\frac{M S T}{M S E}
$$




\section{RESULTS}

\section{Arthropod Pests}

The following arthropod pests were obtained from the cassava plants; whitefly, Convolvulus hawkmoth, centipede, and grasshopper.

\section{Proximate, Mineral and Microbial Contents} of Arthropod Pests

Proximate analysis showed that the highest values for crude protein $(7.64 \%)$, crude fiber $(0.72 \%)$, fat $(5.65 \%)$, ash $(0.79 \%)$ and moisture content (16.05\%) were obtained in whitefly, Convolvulus hawkmoth, centipede, and grasshopper respectively (Figure 2). Meanwhile, there were no significant differences $(P \geq 0.05)$ in the crude fiber values of Convolvulus hawkmoth and Centipede.

Figure 3 shows the mineral contents of selected pests. Ca $(4.53 \mathrm{mg} / 100 \mathrm{~g}), \mathrm{K}(8.28 \mathrm{mg} / 100 \mathrm{~g})$, $\mathrm{Na}(5.81 \mathrm{mg} / 100 \mathrm{~g}), \mathrm{P}(6.86 \mathrm{mg} / 100 \mathrm{~g}), \mathrm{Fe}$ $(3.51 \mathrm{mg} / 100 \mathrm{~g})$ and $\mathrm{Mg}(2.47 \mathrm{mg} / 100 \mathrm{~g})$ were found to be highest in whitefly, grasshopper, Centipede and Convolvulus hawkmoth respectively. There were significant differences $(\mathrm{P} \leq \mathrm{0.05})$ in the $\mathrm{Ca}, \mathrm{K}, \mathrm{Na}, \mathrm{P}, \mathrm{Fe}$, and $\mathrm{Mg}$ values for the selected pests. The centipede had the lowest $\mathrm{Mg}, \mathrm{Fe}$, and $\mathrm{K}$ values of $1.18 \mathrm{mg} / 100$ $\mathrm{g}, 1.48 \mathrm{mg} / 100 \mathrm{~g}$, and $5.70 \mathrm{mg} / 100 \mathrm{~g}$, respectively. There were no significant differences $(p \geq 0.05)$ in the phosphorus values of Convolvulus hawkmoth, Centipede, and grasshopper. Grasshopper recorded the lowest Ca content of $3.03 \mathrm{mg} / 100 \mathrm{~g}$ while whitefly had the lowest $\mathrm{Na}$ content of $3.53 \mathrm{mg} / 100 \mathrm{~g}$.
In Figure 4, microbial content analysis shows that the highest values for TBC $\left(0.67 \times 10^{5} \mathrm{cfu} \mathrm{g}\right.$ $\left.{ }^{1}\right)$, TFC $\left(0.08 \times 10^{5} \mathrm{cfu} \mathrm{g}^{-1}\right)$, and TCC $\left(0.23 \times 10^{5}\right.$ cfu $\mathrm{g}^{-1}$ ) were obtained in Whitefly and grasshopper. There were no significant differences $(P \geq 0.05)$ in the total fungi counts of Whitefly, Convolvulus hawkmoth, and Centipede. Convolvulus hawkmoth $\left(0.47 \times 10^{5}\right.$ $\mathrm{cfu} \mathrm{g}^{-1}$ ) showed the lowest total bacterial count, while whitefly recorded the lowest total coliform count of $0.10 \times 10^{5} \mathrm{cfu} \mathrm{g}^{-1}$.

In Figure 5, the highest values for crude protein $(7.70 \%)$, crude fiber $(0.74 \%)$, fat $(5.71 \%)$, ash $(0.81 \%)$ and moisture content $(16.11 \%)$ were obtained in Convolvulus hawkmoth and grasshopper respectively. Meanwhile, the crude fiber content in Convolvulus hawkmoth and Centipede showed there were no significant differences $(P \geq 0.05)$ in their values.

Figure 6 showed that $\mathrm{Ca}(4.60 \mathrm{mg} / 100 \mathrm{~g}), \mathrm{K}$ $(8.34 \mathrm{mg} / 100 \mathrm{~g}), \mathrm{Na}(5.87 \mathrm{mg} / 100 \mathrm{~g}), \mathrm{P}(6.92$ $\mathrm{mg} / 100 \mathrm{~g}), \mathrm{Fe}(3.57 \mathrm{mg} / 100 \mathrm{~g})$ and $\mathrm{Mg}(2.53$ $\mathrm{mg} / 100 \mathrm{~g}$ ) were found to be highest in whitefly, grasshopper, Centipede and Convolvulus hawkmoth respectively. There were significant differences $(P \leq 0.05)$ in the $\mathrm{Ca}, \mathrm{K}, \mathrm{Na}, \mathrm{P}, \mathrm{Fe}$, and $\mathrm{Mg}$ values for the selected pests. Centipede had the lowest $\mathrm{Mg}, \mathrm{Fe}$, and $\mathrm{K}$ values of 1.24 $\mathrm{mg} / 100 \mathrm{~g}, 1.54 \mathrm{mg} / 100 \mathrm{~g}$, and $5.76 \mathrm{mg} / 100 \mathrm{~g}$, respectively. Grasshopper recorded the lowest Ca content of $3.09 \mathrm{mg} / 100 \mathrm{~g}$. There were no significant differences $(P \geq 0.05)$ in the phosphorus values of Centipede and grasshopper $(6.92 \mathrm{mg} / 100 \mathrm{~g})$.

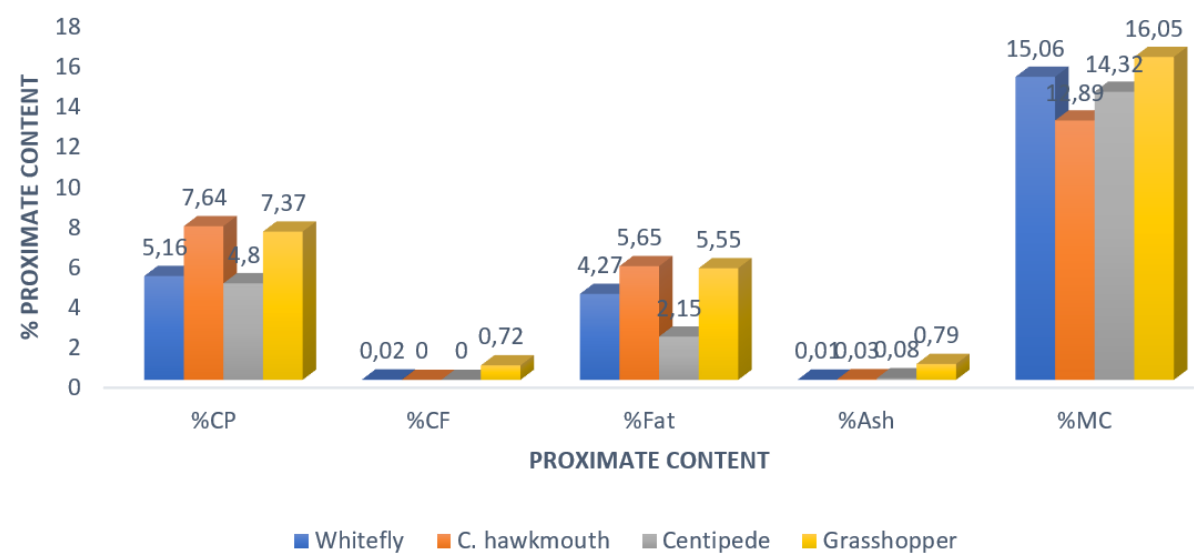

Figure 2. Proximate analysis of pests obtained from $A B F 1$ ( $A B F 1=A$ bapawa Farmland 1$)(C P=$ Crude Protein, $\mathrm{CF}=$ Crude Fiber, $\mathrm{MC}=$ Moisture Content) 


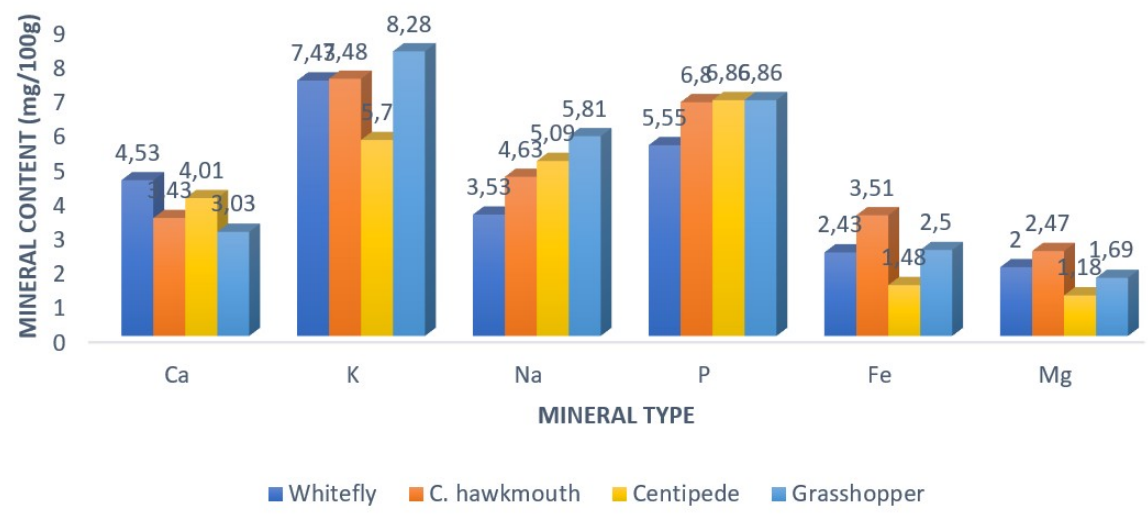

Figure 3. Mineral contents of selected pests obtained from ABF1 ( $A B F 1=A b a p a w a$ Farmland 1)
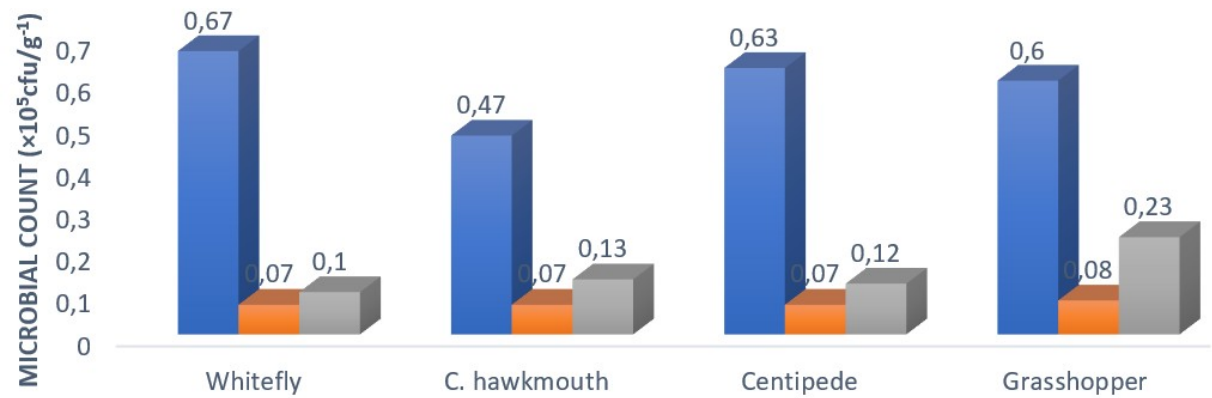

INSECT PEST

$\square \mathrm{TBC} \quad$ TFC $\square \mathrm{TCC}$

Figure 4. Microbial content analysis of pests obtained from ABF1 ( $A B F 1=A b a p a w a$ Farmland 1$)$

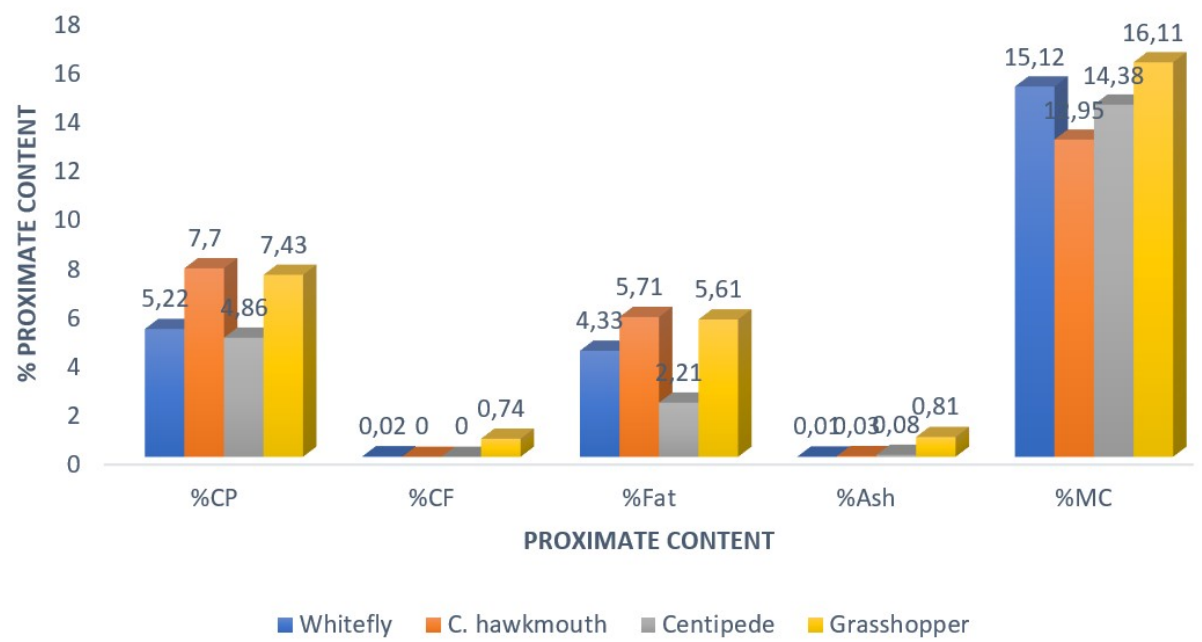

Figure 5. Proximate analysis of pests obtained from ABF2 (ABF $2=A$ bapawa Farmland 2 ) 


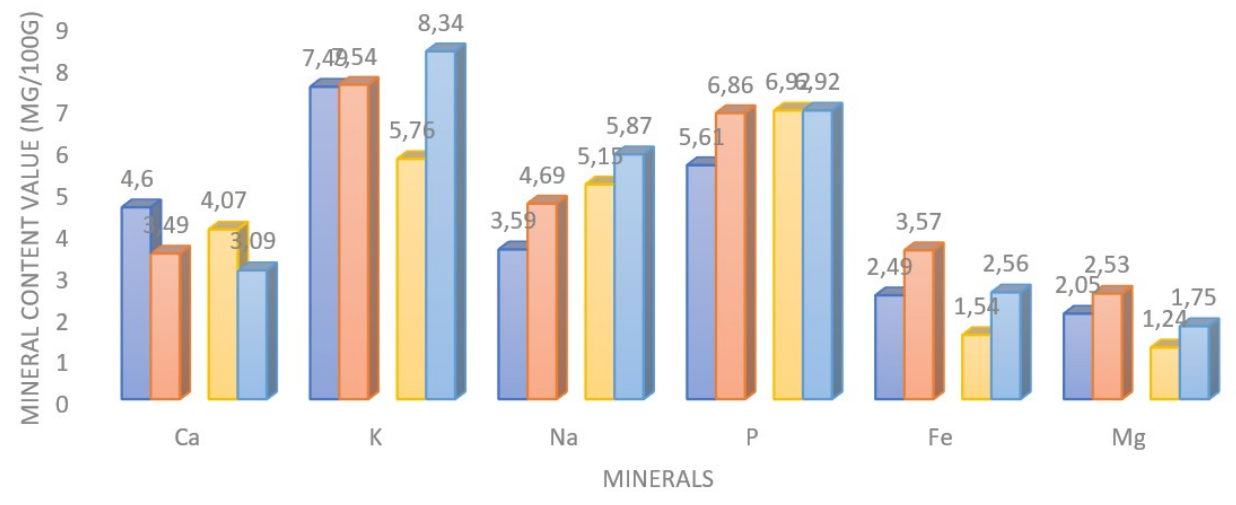

$\square$ Whitefly $\square$ C. hawkmouth $\square \quad \square$ Centipede $\square$ Grasshopper

Figure 6. Mineral content analysis of pests obtained from ABF2 (ABF 2=Abapawa Farmland

The highest values for TBC $\left(0.69 \times 10^{5} \mathrm{cfu} \mathrm{g}^{-1}\right)$ and TCC $\left(0.23 \times 105 \mathrm{cfu}^{-1}\right)$ were obtained in whitefly and grasshopper, respectively (Figure $7)$. There were no significant differences $(P \geq 0.05)$ in the total fungi counts of Whitefly, Convolvulus hawkmoth, grasshopper, and Centipede. Convolvulus hawkmoth $\left(0.47 \times 10^{5} \mathrm{cfu} \mathrm{g}^{-1}\right)$ showed the lowest total bacterial count, while whitefly recorded the lowest total coliform count of $0.10 \times 10^{5} \mathrm{cfu} \mathrm{g}^{-1}$.

In Figure 8, there were no significant differences in the $(P \geq 0.05)$ crude fiber contents of Convolvulus hawkmoth and Centipede. The proximate analysis shows that the highest values for crude protein (7.84\%), crude fiber $(0.79 \%)$, fat $(5.85 \%)$, ash $(0.85 \%)$, and moisture content (16.25\%) were obtained in Convolvulus hawkmoth and grasshopper respectively.

In Figure 9, the mineral content analysis showed that $\mathrm{Ca}(4.73 \mathrm{mg} / 100 \mathrm{~g}), \mathrm{K}$ (8.48 $\mathrm{mg} / 100 \mathrm{~g}), \mathrm{Na}(6.01 \mathrm{mg} / 100 \mathrm{~g}), \mathrm{P}$ (7.06 $\mathrm{mg} / 100 \mathrm{~g})$, Fe $(3.71 \mathrm{mg} / 100 \mathrm{~g})$ and $\mathrm{Mg}(2.67$ $\mathrm{mg} / 100 \mathrm{~g})$ were found to be highest in whitefly, grasshopper, Centipede and Convolvulus hawkmoth respectively. There were significant differences ( $\mathrm{P} \leq \mathrm{0.05})$ in the $\mathrm{Ca}, \mathrm{K}, \mathrm{Na}, \mathrm{P}, \mathrm{Fe}$, and $\mathrm{Mg}$ values for the selected pests. The centipede had the lowest $\mathrm{Mg}, \mathrm{Fe}, \mathrm{Na}$, and $\mathrm{K}$ values of $1.38 \mathrm{mg} / 100 \mathrm{~g}, 1.68 \mathrm{mg} / 100 \mathrm{~g}, 5.29$ $\mathrm{mg} / 100 \mathrm{~g}$, and $5.90 \mathrm{mg} / 100 \mathrm{~g}$, respectively. There were no significant differences $(P \geq 0.05)$ in the phosphorus values of Centipede and grasshopper. Grasshopper recorded the lowest Ca content of $3.23 \mathrm{mg} / 100 \mathrm{~g}$ while whitefly had the lowest $\mathrm{Na}$ content of $3.73 \mathrm{mg} / 100 \mathrm{~g}$. There were significant differences $(P \leq 0.05)$ in the values obtained for potassium in Centipede, Whitefly and Convolvulus hawkmoth.
In Figure 10, there were significant differences $(P \leq 0.05)$ in the total bacterial count of the sampled pests. The highest values of TBC $(0.73$ $\left.\times 10^{5} \mathrm{cfu} \mathrm{g}^{-1}\right)$, TFC $\left(0.08 \times 10^{5} \mathrm{cfu} \mathrm{g}^{-1}\right)$ and TCC $\left(0.23 \times 10^{5} \mathrm{cfu} \mathrm{g}^{-1}\right)$ were obtained in Whitefly and grasshopper respectively. There were no significant differences $(P \geq 0.05)$ in the total fungi counts of Whitefly and Convolvulus hawkmoth. Convolvulus hawkmoth had the lowest total bacterial count of $0.47 \times 10^{5} \mathrm{cfu} \mathrm{g}^{-1}$, while whitefly recorded the lowest total coliform count of $0.10 \times 10^{5} \mathrm{cfu} \mathrm{g}^{-1}$. There were significant differences in the TFC of Centipede and grasshopper.

In Figure 11, the highest crude protein $(7.74 \%)$, crude fiber $(0.75 \%)$, fat $(5.75 \%)$, ash $(0.82 \%)$, and moisture content (16.15\%) values were obtained in Convolvulus hawkmoth and grasshopper respectively. Lowest ash content values were obtained in whitefly $(0.01 \%)$, while Convolvulus hawkmoth had the lowest moisture content of $12.99 \%$.

In Figure 12, Ca $(4.63 \mathrm{mg} / 100 \mathrm{~g}), \mathrm{K}(8.38 \mathrm{mg} /$ $100 \mathrm{~g}), \mathrm{Na}(5.91 \mathrm{mg} / 100 \mathrm{~g}), \mathrm{P}(6.97 \mathrm{mg} / 100$ g), Fe (3.61 mg/100 g) and $\mathrm{Mg}(2.57 \mathrm{mg} / 100$ g) were highest in whitefly, grasshopper, Centipede and Convolvulus hawkmoth respectively. There were significant differences $(\mathrm{P} \leq \mathrm{0.05})$ in the $\mathrm{Ca}, \mathrm{K}, \mathrm{Na}, \mathrm{P}, \mathrm{Fe}$, and $\mathrm{Mg}$ values for the selected pests. The centipede had the lowest $\mathrm{Mg}, \mathrm{Fe}, \mathrm{Na}$, and $\mathrm{K}$ values of 1.28 $\mathrm{mg} / 100 \mathrm{~g}, 1.58 \mathrm{mg} / 100 \mathrm{~g}, 5.19 \mathrm{mg} / 100 \mathrm{~g}$, and $5.80 \mathrm{mg} / 100 \mathrm{~g}$, respectively. Grasshopper recorded the lowest Ca content of $3.13 \mathrm{mg} / 100$ $\mathrm{g}$ while whitefly had the lowest $\mathrm{Na}$ content of $3.63 \mathrm{mg} / 100 \mathrm{~g}$. 
n Figure 13, there were significant differences $(P \leq 0.05)$ in the total bacterial count of the sampled pests. The highest values of TBC $(0.70$ $\left.\times 10^{5} \mathrm{cfu} \mathrm{g}^{-1}\right)$, TFC $\left(0.08 \times 10^{5} \mathrm{cfu} \mathrm{g}^{-1}\right)$ and TCC $\left(0.23 \times 10^{5} \mathrm{cfu} \mathrm{g}^{-1}\right)$ which were obtained in Whitefly and grasshopper respectively. There were significant differences in the total fungi counts of Whitefly $\left(0.03 \times 10^{5} \mathrm{cfu} \mathrm{g}^{-1}\right)$,

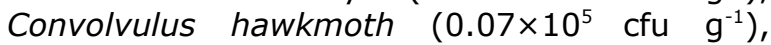
Centipede $\left(0.05 \times 10^{5} \mathrm{cfu} \mathrm{g}^{-1}\right)$ and grasshopper

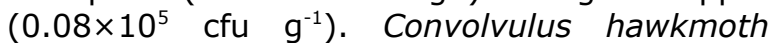
$\left(0.47 \times 10^{5} \mathrm{cfu} \mathrm{g}^{-1}\right)$ had the lowest total bacterial count while whitefly recorded the lowest total coliform count of $0.05 \times 10^{5} \mathrm{cfu} \mathrm{g}^{-1}$.

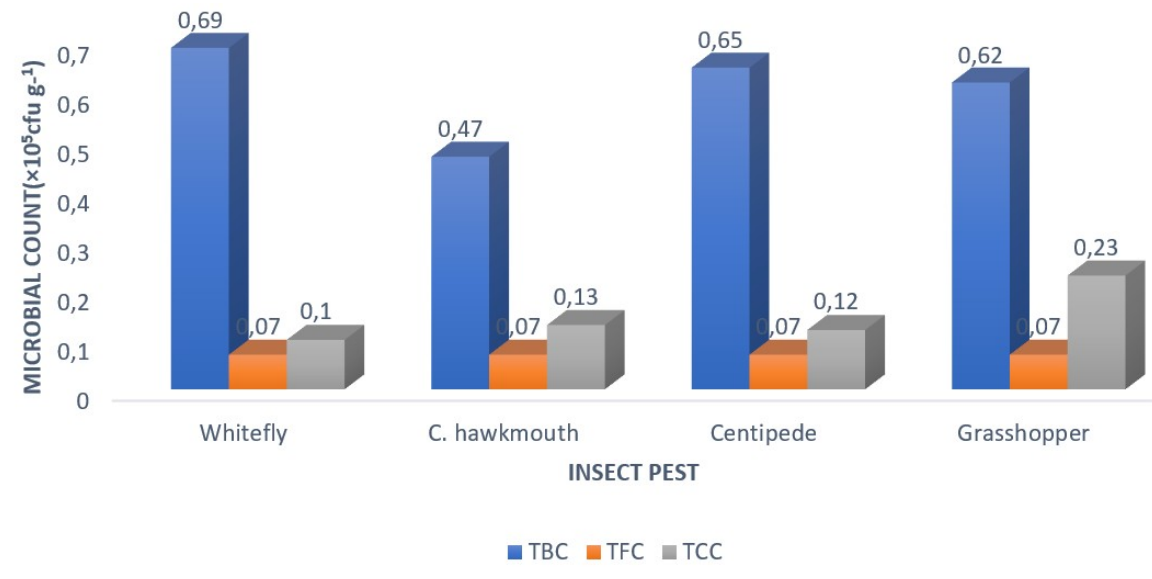

Figure 7. Microbial count analysis of pests obtained from ABF2 (ABF $2=A$ bapawa Farmland 2). TBC $=$ Total Bacterial Count, $\mathrm{TCC}=$ Total Coliform Count, TFC $=$ Total Fungal Count

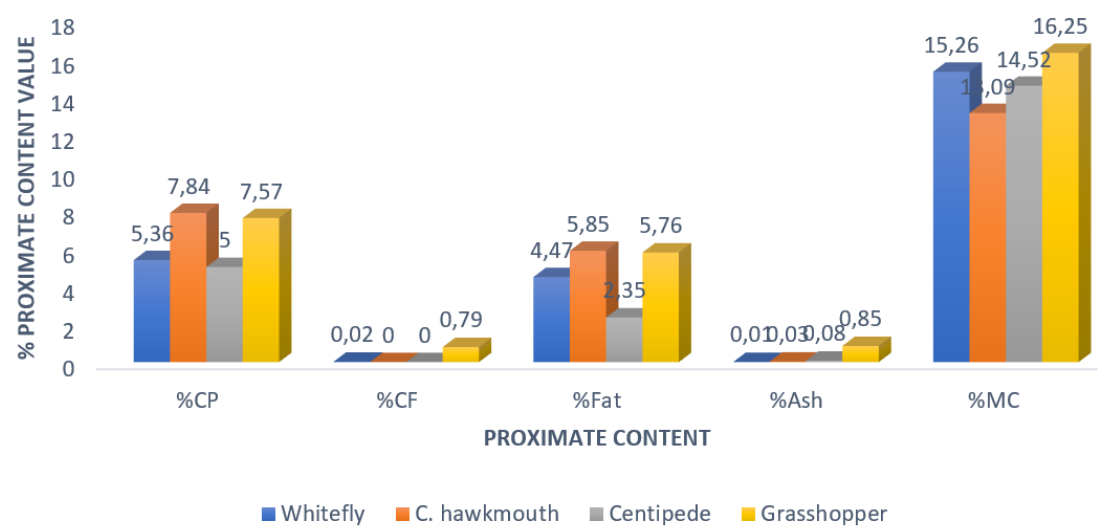

Figure 8. Proximate analysis of pests obtained from ABF3 ( $A B F 3=A$ bapawa Farmland 3$)(C P=$ Crude Protein, $\mathrm{CF}=$ Crude Fiber, $\mathrm{MC}=$ Moisture Content)

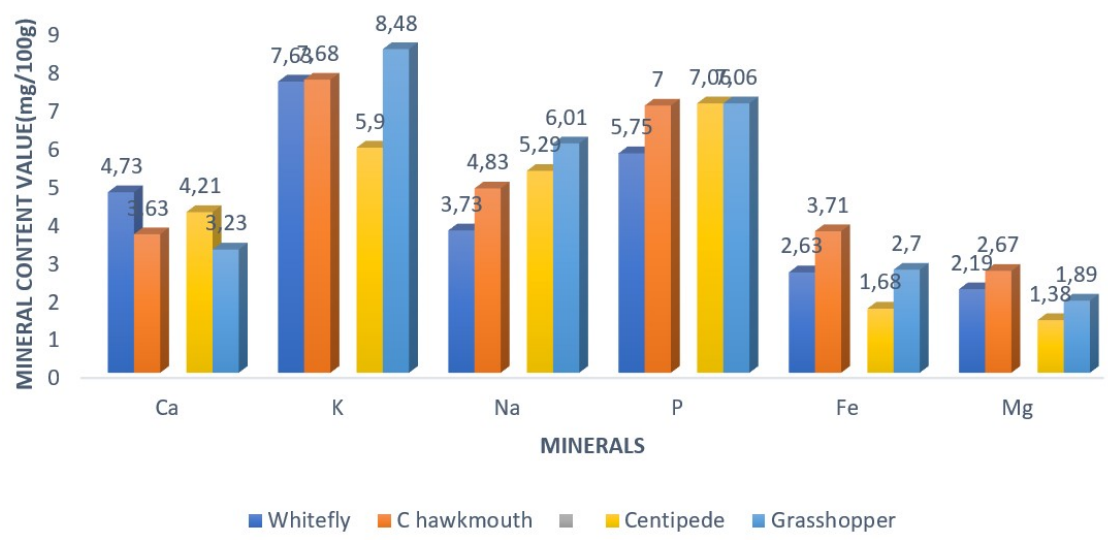

Figure 9. Mineral content analysis of pests obtained from ABF3 ( $A B F 3=A$ bapawa Farmland 3) 


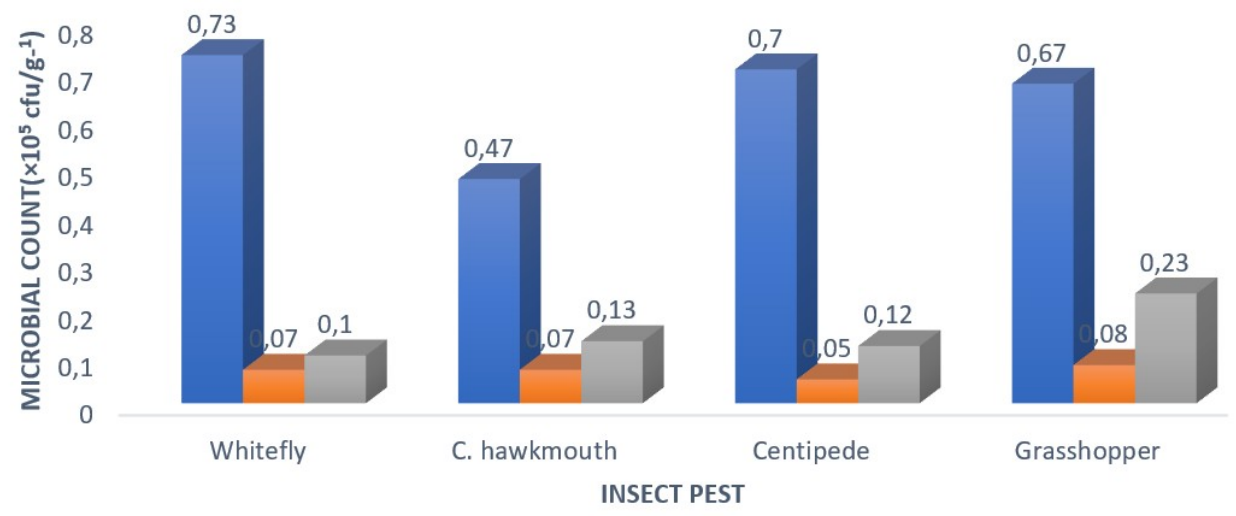

$\because \mathrm{TBC} \backsim \mathrm{TFC} \square \mathrm{TCC}$

Figure 10. Microbial count of pests obtained from ABF3 ( $A B F 3=A$ bapawa Farmland 3). TBC=Total Bacterial Count, $\mathrm{TCC}=$ Total Coliform Count, TFC $=$ Total Fungal Count

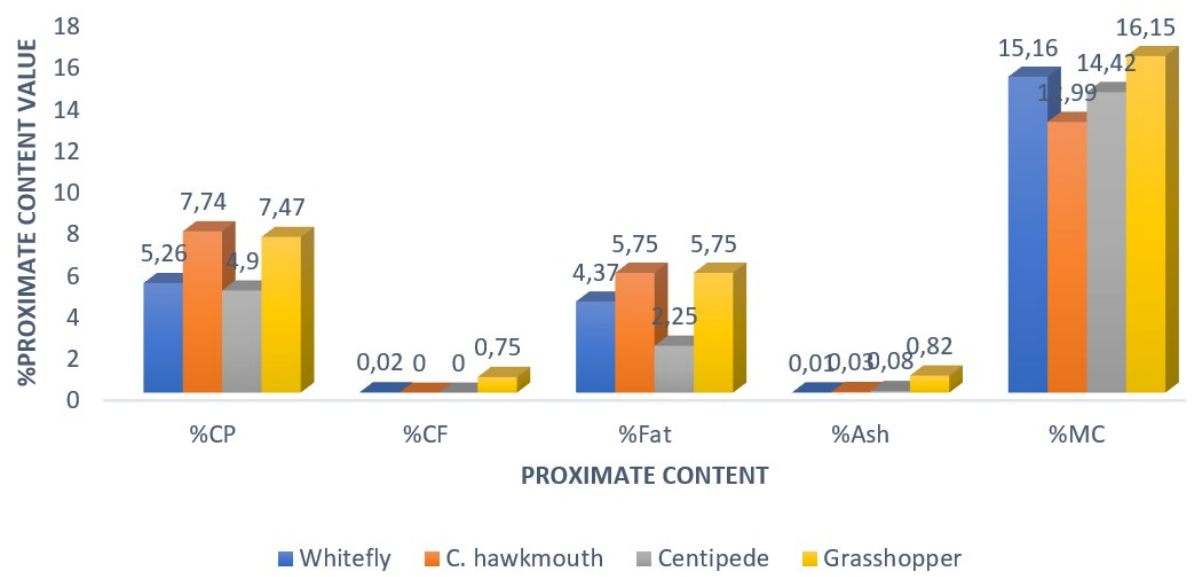

Figure 11. Proximate analysis of pests obtained from ABF4 (ABF4=Abapawa Farmland 4)

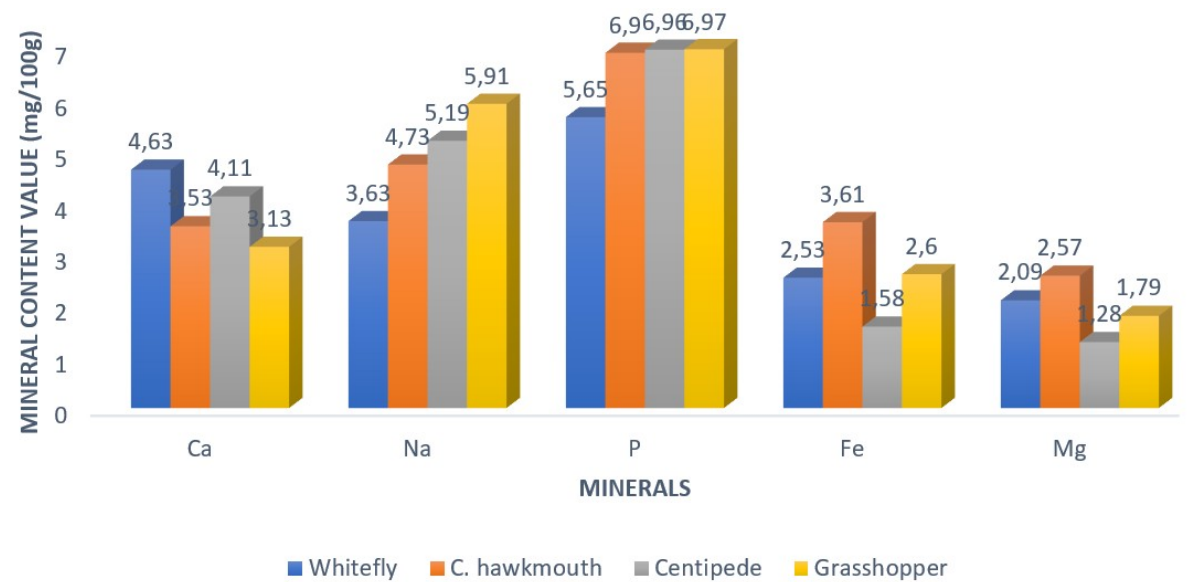

Figure 12. Mineral content analysis of pests obtained from ABF4 (ABF4=Abapawa Farmland 4) 

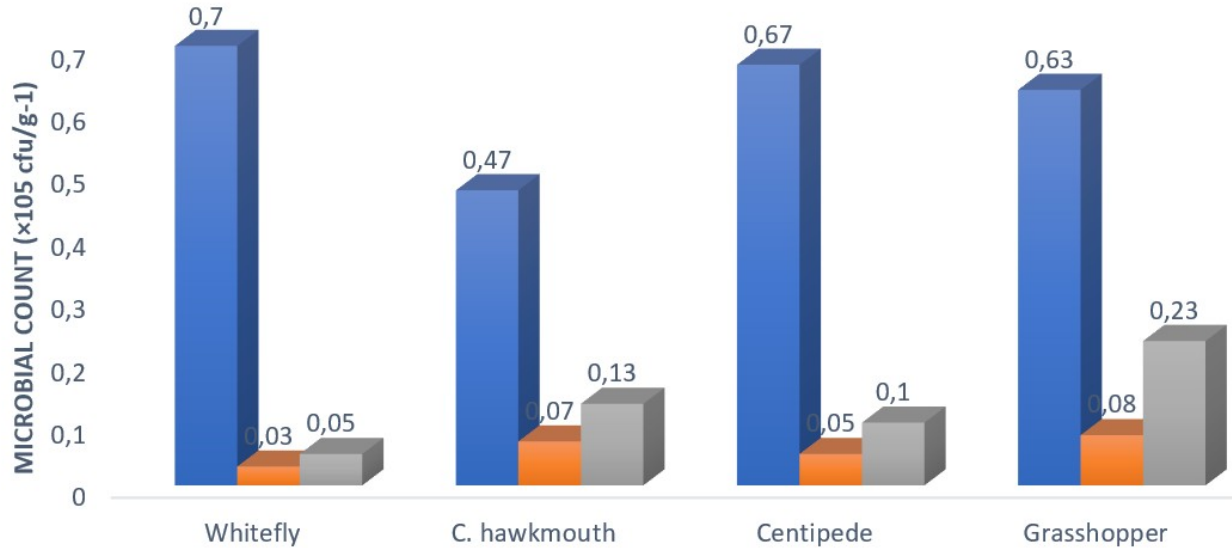

$\square \mathrm{TBC} \square \mathrm{TFC} \square \mathrm{TCC}$

Figure 13. Microbial content analysis of pests obtained from ABF4 (ABF4=Abapawa Farmland 4). TBC $=$ Total Bacterial Count, $\mathrm{TCC}=$ Total Coliform Count, TFC $=$ Total Fungal Count

\section{Phytochemical Content in Various Parts of Manihot Esculenta}

In Table 1, alkaloids were obtained in comparatively high concentrations in all parts of the plant (Manihot esculenta). The lowest phenol and alkaloid content values of
$0.10 \pm 0.00 \mathrm{ppm}$ and $3.51 \pm 2.45 \mathrm{ppm}$ respectively were obtained in the cassava branch. The leaf recorded the highest phenol value of $0.74 \pm 0.01 \mathrm{ppm}$. The highest flavonoid content of $2.06 \pm 0.05 \mathrm{ppm}$ was obtained in the root of Manihot esculenta.

Table 1. Phytochemical content (ppm) in various parts of Manihot esculenta

\begin{tabular}{lcccc}
\hline Sample & Alkaloids & Flavonoids & Tannins & Phenols \\
\hline Leaf & $2.83 \pm 0.95$ & $0.98 \pm 0.05$ & $2.98 \pm 0.03$ & $0.74 \pm 0.01$ \\
Stem & $2.48 \pm 0.15$ & $1.31 \pm 0.37$ & $1.51 \pm 0.02$ & $0.18 \pm 0.01$ \\
Root & $2.83 \pm 0.15$ & $2.06 \pm 0.05$ & $0.85 \pm 0.01$ & $0.25 \pm 0.01$ \\
Branch & $3.51 \pm 2.45$ & $1.42 \pm 0.06$ & $1.89 \pm 0.35$ & $0.10 \pm 0.00$ \\
\hline
\end{tabular}

Mineral, Phytochemicals, Proximate and Vitamin Contents of Cassava Leaves

The minerals analyzed in this study occurred in varying quantities (Table 2). Cassava leaves contained high quantities of $\mathrm{Ca}$. The highest quantity (1152.84 $\pm 0.67 \mathrm{mg} / 100 \mathrm{~g})$ was obtained in ABF4 followed by ABF5 $(1148.72 \pm 1.09 \mathrm{mg} / \mathrm{kg})$, ABF3 $(1141.23 \pm 2.12$ $\mathrm{mg} / \mathrm{kg}), \operatorname{ABF} 2(1125.8 \pm 0.89 \mathrm{mg} / \mathrm{kg})$, and $\mathrm{ABF} 1$ $(791.96 \pm 0.16 \mathrm{mg} / \mathrm{kg})$. $\mathrm{K}$ was also obtained in high quantities with ABF4 (764.13 $\pm 1.14 \mathrm{mg} / \mathrm{kg}$ ) containing the highest quantity followed by ABF5 (761.49 $0.65 \mathrm{mg} / \mathrm{kg})$, ABF3 $(760.68 \pm 0.38 \mathrm{mg} / \mathrm{kg}), A B F 1(759.48 \pm 1.21 \mathrm{mg} /$ $\mathrm{kg})$ and $A B F 2(692.82 \pm 0.92 \mathrm{mg} / \mathrm{kg})$.

Table 2. The mineral content of cassava leaves $(\mathrm{mg} / \mathrm{kg}$ )

\begin{tabular}{lccccc}
\hline & ABF1 & ABF2 & ABF3 & ABF4 & ABF5 \\
\hline $\mathrm{Na}$ & $25.58 \pm 0.45^{\mathrm{a}}$ & $27.09 \pm 0.30^{\mathrm{c}}$ & $27.05 \pm 0.07^{\mathrm{c}}$ & $28.25 \pm 0.34^{\mathrm{d}}$ & $26.93 \pm 0.01^{\mathrm{d}}$ \\
$\mathrm{K}$ & $759.48 \pm 1.21^{\mathrm{c}}$ & $692.82 \pm 0.92^{\mathrm{g}}$ & $760.68 \pm 0.38^{\mathrm{g}}$ & $764.13 \pm 1.14^{\mathrm{h}}$ & $761.49 \pm 0.65^{\mathrm{h}}$ \\
$\mathrm{Ca}$ & $791.96 \pm 0.16^{\mathrm{c}}$ & $1125.8 \pm 0.89^{\mathrm{h}}$ & $1141.23 \pm 2.12^{\mathrm{h}}$ & $1152.84 \pm 0.67^{\mathrm{i}}$ & $1148.72 \pm 1.09^{\mathrm{i}}$ \\
$\mathrm{P}$ & $66.68 \pm 3.82^{\mathrm{ab}}$ & $76.22 \pm 0.83^{\mathrm{d}}$ & $76.22 \pm 0.51^{\mathrm{d}}$ & $76.60 \pm 0.34^{\mathrm{e}}$ & $75.23 \pm 0.87^{\mathrm{e}}$ \\
$\mathrm{Mg}$ & $313.12 \pm 0.50^{\mathrm{ab}}$ & $320.75 \pm 1.14^{\mathrm{e}}$ & $317.60 \pm 0.62^{\mathrm{e}}$ & $330.40 \pm 0.78^{\mathrm{f}}$ & $333.44 \pm 0.25^{\mathrm{f}}$ \\
$\mathrm{Fe}$ & $412.70 \pm 0.58^{\mathrm{d}}$ & $422.48 \pm 0.90^{\mathrm{f}}$ & $418.15 \pm 0.31^{\mathrm{f}}$ & $416.13 \pm 0.88^{\mathrm{g}}$ & $416.79 \pm 1.10^{\mathrm{g}}$ \\
$\mathrm{Zn}$ & $17.52 \pm 0.58^{\mathrm{a}}$ & $17.54 \pm 0.31^{\mathrm{b}}$ & $18.44 \pm 0.80^{\mathrm{b}}$ & $22.46 \pm 0.17^{\mathrm{c}}$ & $21.72 \pm 0.04^{\mathrm{c}}$ \\
$\mathrm{Mn}$ & $16.90 \pm 0.03^{\mathrm{a}}$ & $18.55 \pm 0.04^{\mathrm{b}}$ & $17.15 \pm 0.66^{\mathrm{b}}$ & $18.77 \pm 0.44^{\mathrm{b}}$ & $18.43 \pm 0.14^{\mathrm{b}}$ \\
$\mathrm{Cu}$ & $2.62 \pm 0.01^{\mathrm{a}}$ & $4.65 \pm 0.02^{\mathrm{a}}$ & $5.26 \pm 0.03^{\mathrm{a}}$ & $4.73 \pm 0.02^{\mathrm{a}}$ & $5.27 \pm 0.69^{\mathrm{a}}$ \\
\hline
\end{tabular}

Columns with values that have the same letter show that there is no significant differences $(P \geq 0.05)$ between the values; columns with values that have different letters show that there is a significant difference $(P \leq 0.05)$ between the values. $A B F 1=A$ bapawa Farm $1, A B F 2=$ Abapawa Farm 2, ABF3= Abapawa Farm 3, ABF4= Abapawa Farm 4, ABF5= Abapawa Farm 5. 
The cassava leaves were also found to contain high quantities of Fe. The highest quantity of Fe was obtained in ABF2 (422.48 $\pm 0.90 \mathrm{mg} / \mathrm{kg}$ ). However, $\mathrm{Cu}$ was obtained in low quantities. ABF1 recorded the lowest $\mathrm{Cu}$ content of $2.62 \pm 0.01 \mathrm{mg} / \mathrm{kg}$, while the highest $\mathrm{Cu}$ content was obtained in ABF5 (5.27 $\pm 0.69 \mathrm{mg} / \mathrm{kg}$ ). Table 2 showed that there were significant differences $(P \leq 0.05)$ in the mineral quantity values. However, there were no significant differences $(P \geq 0.05)$ in the $Z n$ and $M n$ values of $A B F 1$ and $A B F 2$.

This study revealed that cassava leaves contain the following phytochemical constituents; cyanogenic glycosides, flavonoids, saponin, alkaloids, phytate, oxalate, trypsin inhibitor, and phenol. The phytochemical contents analyzed in Table 3 revealed that cyanogenic glycosides were obtained in very high amounts. The highest cyanogenic glycoside value was obtained in ABF2 (32.82 $\pm 0.16 \mathrm{mg} / 100 \mathrm{~g})$, followed by ABF4 (32.70 $0.29 \mathrm{mg} / 100 \mathrm{~g})$, ABF3 (31.67 $\pm 0.04 \mathrm{mg} / 100 \mathrm{~g}), \quad$ ABF2 $(30.96 \pm 0.24 \mathrm{mg} / 100 \mathrm{~g})$ and $A B F 1(30.89 \pm 0.57$ $\mathrm{mg} / 100 \mathrm{~g})$. tannin was obtained in low amounts. ABF3 contained the lowest tannin value of $0.16 \pm 0.01 \mathrm{mg} / 100 \mathrm{~g}$. Flavonoids were also obtained in appreciable amounts. ABF3 had the highest flavonoid content of $3.90 \pm 0.01 \mathrm{mg} /$ $100 \mathrm{~g}$. There were significant differences $(P \leq 0.05)$ in the phytochemical contents in Table 3. However, there were no significant differences $(P \geq 0.05)$ in the tannin, phenol, trypsin inhibitor, phytate and oxalate values in ABF1.

Table 3. Phytochemical content of cassava leaves (mg/100 g)

\begin{tabular}{lccccc}
\hline & ABF1 & ABF2 & ABF3 & ABF4 & ABF5 \\
\hline ALKALOID & $1.30 \pm 0.01^{\mathrm{b}}$ & $1.22 \pm 0.01^{\mathrm{c}}$ & $1.63 \pm 0.01^{\mathrm{e}}$ & $2.31 \pm 0.55^{\mathrm{b}}$ & $1.78 \pm 0.01^{\mathrm{d}}$ \\
SAPONIN & $3.21 \pm 0.03^{\mathrm{c}}$ & $3.63 \pm 0.04^{\mathrm{d}}$ & $3.15 \pm 0.01^{\mathrm{f}}$ & $3.14 \pm 0.01^{\mathrm{c}}$ & $3.18 \pm 0.02^{\mathrm{f}}$ \\
FLAVONOID & $3.71 \pm 0.02^{\mathrm{c}}$ & $3.64 \pm 0.02^{\mathrm{d}}$ & $3.90 \pm 0.01^{\mathrm{g}}$ & $2.87 \pm 0.05^{\mathrm{bc}}$ & $2.89 \pm 0.04^{\mathrm{h}}$ \\
TANIN & $0.22 \pm 0.01^{\mathrm{a}}$ & $0.25 \pm 0.01^{\mathrm{a}}$ & $0.16 \pm 0.01^{\mathrm{a}}$ & $0.22 \pm 0.01^{\mathrm{a}}$ & $0.17 \pm 0.01^{\mathrm{a}}$ \\
PHENOL & $0.17 \pm 0.01^{\mathrm{a}}$ & $0.17 \pm 0.01^{\mathrm{a}}$ & $0.14 \pm 0.01^{\mathrm{a}}$ & $0.19 \pm 0.01^{\mathrm{a}}$ & $0.15 \pm 0.01^{\mathrm{a}}$ \\
T INHIBITOR & $0.42 \pm 0.01^{\mathrm{a}}$ & $0.41 \pm 0.02^{\mathrm{ab}}$ & $0.31 \pm 0.01^{\mathrm{b}}$ & $0.25 \pm 0.01^{\mathrm{a}}$ & $0.33 \pm 0.01^{\mathrm{b}}$ \\
PHYTATE & $0.58 \pm 0.01^{\mathrm{a}}$ & $0.61 \pm 0.02^{\mathrm{b}}$ & $0.63 \pm 0.01^{\mathrm{d}}$ & $0.66 \pm 0.01^{\mathrm{a}}$ & $0.65 \pm 0.01^{\mathrm{c}}$ \\
OXALATE & $0.63 \pm 0.01^{\mathrm{a}}$ & $0.64 \pm 0.02^{\mathrm{b}}$ & $0.55 \pm 0.01^{\mathrm{c}}$ & $0.72 \pm 0.01^{\mathrm{a}}$ & $0.59 \pm 0.01^{\mathrm{c}}$ \\
C GLYCO & $30.89 \pm 0.57^{\mathrm{d}}$ & $30.96 \pm 0.24^{\mathrm{e}}$ & $31.67 \pm 0.04^{\mathrm{h}}$ & $32.70 \pm 0.29^{\mathrm{d}}$ & $32.82 \pm 0.16^{\mathrm{g}}$ \\
\hline
\end{tabular}

Columns with values that have the same letter show that there is no significant differences $(P \geq 0.05)$ between the values; columns with values that have different letters show that there is a significant difference $(P \leq 0.05)$ between the values. Note: T INHIBITOR= Trypsin Inhibitor, $C$ GLYCO= Cyanogenic Glycosides ABF1=Abapawa Farm 1, ABF2= Abapawa Farm 2, ABF3= Abapawa Farm 3, ABF4= Abapawa Farm 4, ABF5= Abapawa Farm 5.

In Table 4, carbohydrates were obtained in appreciable quantities. The highest carbohydrate content of $66.68 \pm 0.08 \%$ was obtained in ABF2. The moisture content values were also appreciable in quantity. The highest moisture content value of $24.1 \pm 0.27 \%$ was obtained in ABF5. Crude proteins and fat were also found in cassava leaves. The highest crude protein and crude fat values of $3.41 \pm 0.13 \%$ and $4.83 \pm 0.02 \%$ were obtained in ABF5. There were significant differences $(P \leq 0.05)$ in the proximate content values.

Table 4. Proximate content of cassava leaves (\%)

\begin{tabular}{lccccc}
\hline & ABF1 & ABF2 & ABF3 & ABF4 & ABF5 \\
\hline CP & $2.5 \pm 0.02^{\mathrm{ab}}$ & $2.33 \pm 0.02^{\mathrm{b}}$ & $3.13 \pm 0.02^{\mathrm{b}}$ & $3.39 \pm 0.01^{\mathrm{b}}$ & $3.41 \pm 0.13^{\mathrm{b}}$ \\
CF & $3.43 \pm 0.02^{\mathrm{c}}$ & $2.96 \pm 0.01^{\mathrm{c}}$ & $3.19 \pm 0.02^{\mathrm{b}}$ & $4.74 \pm 0.03^{\mathrm{c}}$ & $4.83 \pm 0.02^{\mathrm{c}}$ \\
FAT & $2.09 \pm 0.03^{\mathrm{a}}$ & $2.12 \pm 0.01^{\mathrm{a}}$ & $2.14 \pm 0.02^{\mathrm{a}}$ & $2.15 \pm 0.01^{\mathrm{a}}$ & $2.69 \pm 0.03^{\mathrm{a}}$ \\
ASH & $2.86 \pm 0.03^{\mathrm{bc}}$ & $2.91 \pm 0.01^{\mathrm{c}}$ & $2.72 \pm 0.06^{\mathrm{ab}}$ & $3.14 \pm 0.02^{\mathrm{b}}$ & $3.59 \pm 0.04^{\mathrm{b}}$ \\
MOIST & $23.15 \pm 0.34^{\mathrm{d}}$ & $22.99 \pm 0.09^{\mathrm{d}}$ & $23.25 \pm 0.33^{\mathrm{c}}$ & $23.27 \pm 0.24^{\mathrm{d}}$ & $24.1 \pm 0.27^{\mathrm{d}}$ \\
CHO & $65.99 \pm 0.34^{\mathrm{e}}$ & $66.68 \pm 0.08^{\mathrm{e}}$ & $65.57 \pm 0.32^{\mathrm{d}}$ & $63.31 \pm 0.26^{\mathrm{e}}$ & $61.38 \pm 0.23^{\mathrm{e}}$ \\
\hline
\end{tabular}

Columns with values that have the same letter show that there are no significant differences $(P \geq 0.05)$ between the values, columns with values that have different letters show that there is a significant difference $(P \leq 0.05)$ between the values. Note: $C P=$ Crude Protein, $C F=C r u d e$ Fiber, $\mathrm{MC}=$ Moisture Content. ABF1=Abapawa Farm 1, ABF2= Abapawa Farm 2, ABF3= Abapawa Farm 3, ABF4= Abapawa Farm 4, ABF5= Abapawa Farm 5. 
Vitamins $A, B 1, B 2, B 6, C, D, E$, and $K$ were obtained in the cassava leaves (Table 5). Vitamin $\mathrm{C}$ was found in very high quantities compared to the other types of vitamins examined in this work. The highest Vitamin C content of $34.930 \pm 0.136 \mathrm{mg} / 100 \mathrm{~g}$ was obtained. Vitamin K, however, occurred in meager quantities. The lowest vitamin $K$ content of $0.002 \pm 0.000 \mathrm{mg} / 100 \mathrm{~g}$ was obtained in $A B F 1, A B F 2, A B F 4$, and ABF5. There were no significant differences in Vitamins $A, B 1, B 2$, $B 6, E$, and $K$ contents of ABF1 and ABF3.

Table 5. Analysis of vitamins present in cassava leaves (mg/100g)

\begin{tabular}{lccccc}
\hline & ABF1 & ABF2 & ABF3 & ABF4 & ABF5 \\
\hline VIT A & $0.122 \pm 0.001^{\mathrm{a}}$ & $0.126 \pm 0.000^{\mathrm{ab}}$ & $0.307 \pm 0.231^{\mathrm{a}}$ & $0.088 \pm 0.001^{\mathrm{a}}$ & $0.085 \pm 0.001^{\mathrm{b}}$ \\
VIT B1 & $0.220 \pm 0.001^{\mathrm{a}}$ & $0.222 \pm 0.002^{\mathrm{bc}}$ & $0.221 \pm 0.001^{\mathrm{a}}$ & $0.231 \pm 0.001^{\mathrm{a}}$ & $0.234 \pm 0.002^{\mathrm{a}}$ \\
VIT B2 & $0.100 \pm 0.000^{\mathrm{a}}$ & $0.110 \pm 0.000^{\mathrm{ab}}$ & $0.105 \pm 0.001^{\mathrm{a}}$ & $0.112 \pm 0.001^{\mathrm{a}}$ & $0.113 \pm 0.001^{\mathrm{c}}$ \\
VIT B6 & $0.300 \pm 0.005^{\mathrm{a}}$ & $0.280 \pm 0.001^{\mathrm{c}}$ & $0.307 \pm 0.002^{\mathrm{a}}$ & $0.323 \pm 0.002^{\mathrm{a}}$ & $0.322 \pm 0.004^{\mathrm{e}}$ \\
VIT C & $30.290 \pm 0.430^{\mathrm{b}}$ & $34.930 \pm 0.136^{\mathrm{d}}$ & $34.506 \pm 0.367^{\mathrm{b}}$ & $33.163 \pm 0.512^{\mathrm{b}}$ & $34.190 \pm 0.025^{\mathrm{f}}$ \\
VIT D & $0.010 \pm 0.000^{\mathrm{a}}$ & $0.003 \pm 0.000^{\mathrm{a}}$ & $0.004 \pm 0.000^{\mathrm{a}}$ & $0.005 \pm 0.001^{\mathrm{a}}$ & $0.004 \pm 0.001^{\mathrm{a}}$ \\
VIT E & $0.004 \pm 0.000^{\mathrm{a}}$ & $0.002 \pm 0.000^{\mathrm{a}}$ & $0.003 \pm 0.000^{\mathrm{a}}$ & $0.004 \pm 0.000^{\mathrm{a}}$ & $0.004 \pm 0.000^{\mathrm{a}}$ \\
VIT K & $0.002 \pm 0.000^{\mathrm{a}}$ & $0.002 \pm 0.000^{\mathrm{a}}$ & $0.003 \pm 0.000^{\mathrm{a}}$ & $0.002 \pm 0.000^{\mathrm{a}}$ & $0.002 \pm 0.000^{\mathrm{a}}$ \\
\hline
\end{tabular}

Columns with values that have the same letter show that there are no significant differences $(P \geq 0.05)$ between the values; columns with values that have different letters show that there is a significant difference $(P \leq 0.05)$ between the values. $A B F 1=A b a p a w a$ Farm $1, A B F 2=A b a p a w a$ Farm 2, ABF3= Abapawa Farm 3, ABF4= Abapawa Farm 4, ABF5= Abapawa Farm 5.

Antimicrobial Activities of Cassava Leaves

Table 6 shows the antimicrobial activities of the acetone extracts of cassava leaves. There were no significant differences in the zones of inhibitions of $E$. coli, S. aureus, $P$. aeruginosa, in $A B F 1, A B F 2$, and ABF3. The highest zone of inhibition of $13.50 \pm 0.43 \mathrm{~mm}$ was obtained in the culture plates of $S$. aureus in the cassava leaf extracts of ABF4. The lowest zone of inhibition of $2.67 \pm 0.42 \mathrm{~mm}$ was obtained in the culture plates of $A$. flavus in the cassava leaf extracts of ABF3.

Table 6. Antimicrobial activity of acetone extracts of cassava leaves $(\mathrm{mm})$

\begin{tabular}{cccccc}
\hline & $A B F 1$ & $A B F 2$ & $A B F 3$ & $A B F 4$ & $A B F 5$ \\
\hline EC & $10.5 \pm 0.85^{\mathrm{b}}$ & $11.33 \pm 0.67^{\mathrm{b}}$ & $12.17 \pm 0.75^{\mathrm{b}}$ & $13.00 \pm 0.86^{\mathrm{c}}$ & $11.33 \pm 0.62^{\mathrm{b}}$ \\
SA & $12.17 \pm 0.75^{\mathrm{b}}$ & $11.50 \pm 0.62^{\mathrm{b}}$ & $12.83 \pm 0.83^{\mathrm{b}}$ & $13.50 \pm 0.43^{\mathrm{c}}$ & $13.17 \pm 0.48^{\mathrm{c}}$ \\
PA & $10.83 \pm 0.75^{\mathrm{b}}$ & $10.00 \pm 0.78^{\mathrm{b}}$ & $13.33 \pm 0.88^{\mathrm{b}}$ & $10.83 \pm 0.40^{\mathrm{b}}$ & $11.67 \pm 0.42^{\mathrm{b}}$ \\
AF & $3.83 \pm 0.31^{\mathrm{a}}$ & $3.00 \pm 0.37^{\mathrm{a}}$ & $2.67 \pm 0.42^{\mathrm{a}}$ & $3.00 \pm 0.37^{\mathrm{a}}$ & $2.83 \pm 0.31^{\mathrm{a}}$ \\
FO & $3.67 \pm 0.42^{\mathrm{a}}$ & $4.00 \pm 0.52^{\mathrm{a}}$ & $3.17 \pm 0.31^{\mathrm{a}}$ & $2.83 \pm 0.31^{\mathrm{a}}$ & $3.83 \pm 0.31^{\mathrm{a}}$ \\
\hline
\end{tabular}

Columns with values that have the same letter show that there are no significant differences $(P \geq 0.05)$ between the values; columns with values that have different letters show that there is a significant difference $(\mathrm{P} \leq 0.05)$ between the values. Note: $E C=$ Escherichia coli, $S A=$ Staphylococcus aureus, $\mathrm{PA}=$ Pseudomonas aeruginosa, $\mathrm{AF}=$ Aspergillus flavus, $\mathrm{FO}=$ Fusarium oxysporium. ABF1=Abapawa Farm 1, ABF2= Abapawa Farm 2, ABF3= Abapawa Farm 3, ABF4= Abapawa Farm 4, ABF5= Abapawa Farm 5.

In Table 7 there were significant differences $(P \leq 0.05)$ in the zones of inhibition produced in all the culture plates. The highest zone of inhibition of $10.83 \pm 0.31 \mathrm{~mm}$ was obtained in S. aureus culture plates of the leaf extracts of
ABF4 whereas the lowest zone of inhibition value of $2.00 \pm 0.26 \mathrm{~mm}$ was obtained in the $A$. flavus culture plates of the cassava leaf extracts of ABF2.

Table 7. Antimicrobial activity of ethanol extracts of cassava leaves $(\mathrm{mm})$

\begin{tabular}{llllll}
\hline & ABF1 & ABF2 & ABF3 & ABF4 & ABF5 \\
\hline EC & $8.33 \pm 0.56^{\mathrm{b}}$ & $7.00 \pm 0.37^{\mathrm{b}}$ & $9.00 \pm 0.52^{\mathrm{b}}$ & $9.50 \pm 1.18^{\mathrm{bc}}$ & $8.33 \pm 0.56^{\mathrm{b}}$ \\
SA & $10.33 \pm 0.21^{\mathrm{c}}$ & $9.67 \pm 0.67^{\mathrm{c}}$ & $10.83 \pm 0.75^{\mathrm{c}}$ & $10.83 \pm 0.31^{\mathrm{c}}$ & $10.17 \pm 0.54^{\mathrm{c}}$ \\
PA & $8.83 \pm 0.75^{\mathrm{b}}$ & $8.17 \pm 0.98^{\mathrm{bc}}$ & $10.17 \pm 0.54^{\mathrm{bc}}$ & $8.33 \pm 0.67^{\mathrm{b}}$ & $9.00 \pm 0.63^{\mathrm{bc}}$ \\
AF & $2.50 \pm 0.22^{\mathrm{a}}$ & $2.00 \pm 0.00^{\mathrm{a}}$ & $2.33 \pm 0.21^{\mathrm{a}}$ & $2.00 \pm 0.26^{\mathrm{a}}$ & $2.17 \pm 0.17^{\mathrm{a}}$ \\
FO & $2.67 \pm 0.21^{\mathrm{a}}$ & $3.00 \pm 0.26^{\mathrm{a}}$ & $2.33 \pm 0.21^{\mathrm{a}}$ & $2.17 \pm 0.17^{\mathrm{a}}$ & $2.83 \pm 0.31^{\mathrm{a}}$ \\
\hline
\end{tabular}

Columns with values that have the same letter show that there are no significant differences $(P \geq 0.05)$ between the values, columns with values that have different letters show that there is a 
significant difference $(\mathrm{P} \leq 0.05)$ between the values Note: $\mathrm{EC}=$ Escherichia coli, $\mathrm{SA}=$ Staphylococcus aureus, $\mathrm{PA}=$ Pseudomonas aeruginosa, $\mathrm{AF}=$ Aspergillus flavus, $\mathrm{FO}=$ Fusarium oxysporium. ABF1 =Abapawa Farm 1, ABF2= Abapawa Farm 2, ABF3= Abapawa Farm 3, ABF4= Abapawa Farm 4, ABF5= Abapawa Farm 5.

\section{DISCUSSION AND CONCLUSION}

All the insects examined in this study contained high quantities of crude protein and crude fat. However, the highest crude protein and crude fat were obtained in $C$. hawkmoth and grasshopper. It is a good indicator that these insects are good sources of protein and fat, especially $C$. hawkmoth. The insects have also been shown to be rich in minerals, which include $\mathrm{Ca}, \mathrm{Na}, \mathrm{K}, \mathrm{P}$, Fe, and $\mathrm{Mg}$. C. hawkmoth, whitefly, and grasshopper, contained the highest quantities of these minerals, especially potassium $(\mathrm{K})$, sodium $(\mathrm{Na})$ and phosphorus (P). Similar reports were recorded by Sani et al. (11). They stated that: the grasshoppers analyzed in their work had a high percentage of fat. Paiko et al. (12) stated that Sodium, potassium, and phosphorus concentration of $115 \pm 0.07,132.5 \pm 0.08$, and $126.30 \pm 0.50$ $\mathrm{mg} / 100 \mathrm{~g}$ dry weight were obtained respectively in their study. However, lower potassium, sodium, and phosphorus contents were obtained in this study compared to what Paiko et al. (12) observed.

World Health Organization (W.H.O) standard for the fat content of edible insects, as reported in the development of the regional standard for edible crickets was $3.3 \mathrm{~g}$ (12). Fats are essential constituents of daily human diets because they increase the palatability of foods by absorbing and retaining their flavors. These are also important in the structure and biology of cells, and they also assist in the transport of nutritionally essential fat-soluble vitamins. Paiko et al. (12) reported that the crude protein, crude lipid, fiber and carbohydrate contents obtained in their study were $18.39 \pm$ $0.4 \%, 10.5 \pm 1.0 \%, 32.20 \pm 0.20 \%$ and 31.51 $\pm 0.11 \%$ respectively. Paiko et al. (12) reported that the ash quantity $(2.30 \pm 0.30 \%)$ obtained in their study was low. Similar to what Paiko et al. (12) observed in their study, the ash quantity obtained in this present study was also deficient.

The moisture contents of the insects examined in this study were found to be very high. High water content encourages deterioration of the insects hence making them dangerous for consumption. Similar observations were also made by Sani et al. (11). However, Paiko et al. (12) reported lower moisture content compared to the high moisture content obtained in this study. The high moisture content obtained in this study showed that these insects could not be stored for a long period without deterioration. Hence there is a need to employ proper drying and preservation techniques to avoid the quick deterioration of these insects.

The TBC (Total Bacterial Count) and TCC (Total Coliform Count) values of all the insects examined were found to be very high. Hence the need to rid the insects of these bacterial load before consumption. Drying can, however, help reduce the bacterial and total coliform load, hence making the insects suitable for food.

This study revealed that cassava leaves contain the following phytochemical constituents; cyanogenic glycosides, flavonoids, saponin, alkaloids, phytate, oxalate, trypsin inhibitor, and phenol. However, the cyanogenic glycosides obtained in the cassava leaves in this study were very high. The cyanogenic glycosides are plant toxins that can be produced in varieties of plants. Lawal et al. (13) reported that the antinutrients obtained in their study are; cyanide $1.08 \mathrm{mg} / 100 \mathrm{~g}$, saponin $0.28 \mathrm{mg} / 100 \mathrm{~g}$, oxalate $0.61 \mathrm{mg} / 100 \mathrm{~g}$, and phytate $0.78 \mathrm{mg} / 100 \mathrm{~g}$. Similar to what was obtained in this study, Lawal et al. (13) reported that cassava contained high cyanide value as well as a shallow saponin value. However, the content of the cyanogenic glycosides obtained in this study was extremely high compared to what Lawal et al. (13) reported. They also reported that the cyanide concentration of $1.08 \mathrm{mg} / 100 \mathrm{~g}$ could thus be classified as nontoxic because it fell below 10 $\mathrm{mg} / 100 \mathrm{~g}$ powder. Lawal et al. (13) reported that the mineral concentration is in the order; $\mathrm{Mg}>\mathrm{Fe}>\mathrm{Ca}>\mathrm{N}>\mathrm{P}$. however, in this study the mineral concentration is in the following order; $\mathrm{Ca}>\mathrm{K}>\mathrm{Fe}>\mathrm{Mg}>\mathrm{P}>\mathrm{Na}>\mathrm{Mn}>\mathrm{Cu}$. $\mathrm{Ca}$ was obtained in high quantities in this study. Lawal et al. (13), however, reported that Mg was highest in their study. It was also noted in this study that some farms recorded higher mineral content than others. It might be due to the level of minerals in the soils from where the plants take up their nutrients. The values of the mineral content in this study were also found to be higher than what was reported by Oresegun et al. (14). Similar to what was obtained in this 
study Koubala et al. (15) reported that calcium (Ca) followed by potassium (K) and magnesium (Mg) are the main minerals found in cassava leaves.

The crude protein, crude fat, crude fiber, ash and carbohydrate values of cassava leaves, obtained from the different farmlands, reported in this study were lower than the values reported by Lawal et al. (13). However, the moisture content values reported in this study were higher than what was reported by Lawal et al. (13). In this study of all the vitamins examined, vitamin $\mathrm{c}$ was the most abundant in cassava leaves. Koubala et al. (15) also reported high quantities of vitamin $\mathrm{c}$ in cassava leaves.

\section{CONCLUSION}

Cassava leaves could be a good source of nutrients for man due to the avalanche of nutrients such as crude fiber, protein, carbohydrate, minerals ( $\mathrm{Ca}, \mathrm{Na}, \mathrm{K}, \mathrm{Fe}, \mathrm{Mg}, \mathrm{P}$, $\mathrm{Mn}$, and $\mathrm{Cu}$ ) and vitamins. However, the high content of cyanide should be given adequate consideration because cyanide is poisonous to both man and animals. Cassava leaves could also serve as an excellent antimicrobial agent. This study has also shown that the arthropod parasites obtained from the cassava leaves contained high amounts of nutrients and under hygienic conditions could serve as a good nutrient source for man.

\section{REFERENCES}

1. Burns $A E$, Gleadow RM, Zacarias $A M$, Cuambe CE, Miller RE, Cavagnaro TR.Variations in the chemical composition of cassava (Manihotesculenta) leaves and roots as affected by genotypic and environmental variation. Journal of Agricultural and Food Chemistry. 2012; 60(19):4946-4956.

2. Balamurugan T, Anbuselvi S. Physicochemical characteristics of Manihotesculenta plant and its waste. Journal of Chemical and Pharmaceutical Research. 2013; 5(2): 258260.

3. Agre AP, Kouchade S, Odjo T. Diversité et évaluation participative des cultivars du manioc (Manihot esculenta Crantz) au Centre Bénin, International Journal Biological and Chemical Sciences. 2015; 9(1): 388-408.
4. Endlweber K, Scheu S. Interaction between mycorrhizal fungi and collembolan: effects on plant structure of competing plant species. Boil. Fert. Soils. 2007; 43: 741-749.

5. Basset $Y$, Novotny V, Millers S E, Kitching RL. Methodological advances and limitation in canopy entomology. Arthropods of tropical forests. Spatio-Temporal Dynamics and resource use in the canopy. Cambridge University Press. 2003; 3(2), 28-31.

6. Novotny V, Basset $Y$, Kitching RL. Herbivore assemblages and their food resources.Arthropods of tropical forest.SpatioTemporal Dynamics and resource use in the canopy, Cambridge University Press, Cambridge. 2003; 40-53.

7. Boyer AG, Swearingen MA, Blaha CT, Fortson SK, Gremillion KA, Osborn $H$, Moran MD. Seasonal Variation in Top Down and Bottom- Up Processes in a Grassland Arthropod Community. Oecologia. 2003; 136:309-316.

8. Shelton J. Giant Sea Creature Hints at Early Arthropod Evolution Phytochemical. Biological Reviews. 2015; 203-361.

9. Weisser WW, Sieman E. (2004). Insects and Ecosytem Function, Ecological Studies. 2004; 415 (173).

10. Association of Official Analytical Chemists. Official Methods of Analysis of Association of Official Analytical Chemists. 18th Edition, Washington, DC. 2010.

11. Sani I, Haruna M, Abdulhamid A, Warra AA, Bello F, Fakai IM. Assessment of Nutritional Quality and Mineral Composition of Dried Edible Zonocerus variegatus (Grasshopper). Research and Reviews: Journal of Food and Dairy Technology.2014; 2(3): 1-6.

12. Paiko $Y B$, Dagaci $M Z$, Yakubu $A$, Ibrahim IL, Umar MT. Proximate and Mineral Potential of Sun-Dried Short Horn Grasshopper (Zonocerus variegatus) Consumed in Paikoro Local Government, Niger State, Nigeria. Lapai Journal of Applied and Natural Sciences. 2016; 1(2): 16.

13. Lawal I A, Ajayi OA, Owonibi S K, Tajudeen A. Proximate, Minerals and Anti-Nutrient Evaluation of Cassava (Manihot Esculenta crantz) Leaves. International Conference of Science, Engineering \& Environmental Technology. 2017; 2(27): 205-211. 
14. Oresegun $A$, Fagbemiro $O A$, Ilona $P$, Edah B. Nutritional and anti-nutritional composition of cassava leaf protein concentrate from six cassava varieties for use in aqua feed. Journal of Cogent Food and Agriculture. 2016; 2(1): 269-276.
15. Koubala BB, Laya A, Massai $H$, Kouninki $H$, Nukenine EN. Physico-chemical Characterization Leaves from Five Genotypes of Cassava (Manihot esculenta Crantz) Consumed in the Far North Region (Cameroon). American Journal of Food Science and Technology. 2015; 3(2): 40-47. 